\title{
Attaining Food Security in the Wake of Climatic Risks: Lessons from the Delta State of Nigeria
}

\author{
Eromose E. Ebhuoma
}

\section{Contents}

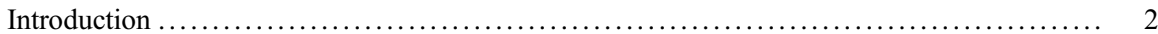

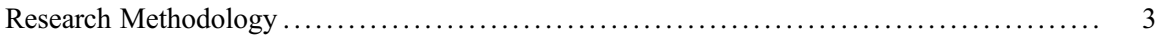

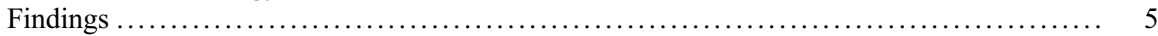

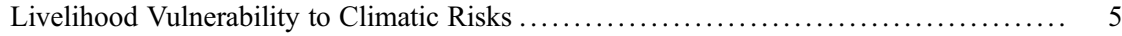

Assets and Food Production Nexus ....................................... 6

Households Still Living Below the Global Poverty Line ......................... 8

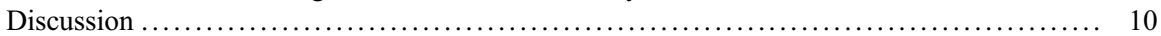

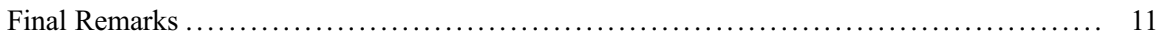

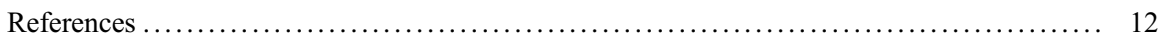

\section{Abstract}

Climate variability and change have undermined the poor rural households' ability in sub-Saharan Africa (SSA) to engage in food production effectively which comprises their primary source of livelihood - partly because it is predominantly rain-fed. Notwithstanding, the rural poor are not docile victims to climatic risks. They actively seek innovative ways to utilize their bundle of assets to reduce the negative effects of climatic risks to ensure household food security. Bundle of assets comprise the financial, human, physical, social, and natural assets owned by, or easily accessible to, an individual. Drawing on primary data obtained qualitatively in the Delta State of Nigeria, this chapter analyzes

\footnotetext{
This chapter was previously published non-open access with exclusive rights reserved by the Publisher. It has been changed retrospectively to open access under a CC BY 4.0 license and the copyright holder is "The Author(s)". For further details, please see the license information at the end of the chapter.
}

\section{E. E. Ebhuoma ( $\square)$}

College of Agriculture and Environmental Sciences, Department of Environmental Sciences, University of South Africa (UNISA), Johannesburg, South Africa

e-mail: ebhuoee@unisa.ac.za 
how Indigenous farmers utilize their bundle of assets to grow their food in the face of a rapidly changing climate. The results indicate that human and social assets played crucial roles in facilitating household food security. Also, social assets facilitated the procurement of other assets necessary to ensure continuity in food production, albeit farmers continue to live under the global poverty line. This chapter critically discusses the implications of these findings in relation to the attainment of both the first and second Sustainable Development Goals (no poverty and zero hunger) by 2030 in the Delta State.

\section{Keywords}

Assets $\cdot$ Climate change $\cdot$ Adaptation $\cdot$ Food security $\cdot$ Indigenous farmers; Nigeria

\section{Introduction}

Climate variability and change have adversely affected various sectors of the global economy including health (Ebhuoma and Gebreslasie 2016), transportation (Jaroszweski et al. 2010), and tourism (Fitchett et al. 2017). However, no sector has been severely affected like agriculture, especially in the developing world (Intergovernmental Panel on Climate Change (IPCC) 2014). This is primary because the agricultural practices embarked upon by poor rural households are extensively dependent on rainfall (Conway and Schipper 2011). Consequently, the slightest deviation of weather patterns from the normal can subject most of the rural poor in developing countries to excruciating poverty and misery due to their inability to obtain their livelihood from food production (IPCC 2014). Furthermore, the vulnerability of the rural poor to climatic risks is exacerbated by weak institutions and agricultural policies, deficiency of social safety nets, inability to purchase farm insurance, and low levels of education (Perez et al. 2015).

In Nigeria, for example, agriculture contributes about $20 \%$ to its gross domestic product (GDP), making it next in line to the country's mainstay after crude oil (National Bureau of Statistics (NBS) 2014). In the last two decades, however, climate variability and change have wreaked havoc in various farming communities, especially in the Delta State where $90 \%$ of rural households are actively engaged in food production (Ifeanyi-obi et al. 2012). Climatic risks have become a huge cause for concern among the rural poor due to growing uncertainty regarding anticipated food productivity and outputs (Mavhura et al. 2013; Nelson et al. 2014). Despite the increased climatic risks that the rural poor in the Delta State and other parts of subSaharan Africa (SSA) are besieged by, they are not docile victims to these threats.

The poor, as Moser (2011) argue, are actively and consistently seeking innovative ways to utilize, modify, and adapt their bundle of assets or capital to reduce the negative effects of climatic risks on their livelihood. Bundle of assets comprises the financial, human, physical, social, and natural assets (Table 1) owned by or easily accessible to an individual. The focus on assets is crucial to facilitating the 
Table 1 Definition of bundle of assets

\begin{tabular}{l|l}
\hline $\begin{array}{l}\text { Asset or } \\
\text { capital }\end{array}$ & Definition \\
\hline Physical & $\begin{array}{l}\text { This includes equipment, infrastructures such as road networks, and other } \\
\text { productive resources owned by individuals, households, communities, or the } \\
\text { country itself }\end{array}$ \\
\hline Financial & $\begin{array}{l}\text { This refers to financial resources available and easily accessible to individuals, } \\
\text { which includes loan, access to credits and savings in a bank or any other financial } \\
\text { institutions }\end{array}$ \\
\hline Human & $\begin{array}{l}\text { This refers to the level of education, skills, health status, and nutrition of } \\
\text { individuals. Labor is closely associated with human capital investments. Health } \\
\text { statuses of individuals impact either positively or negatively on their ability to } \\
\text { work, while skill and level of education is crucial because it influences } \\
\text { individuals return from labor }\end{array}$ \\
\hline Social & $\begin{array}{l}\text { This refers to the norms, rules, obligations, mutuality, and trust embedded in } \\
\text { social relations, social structures, and societies' institutional disposition }\end{array}$ \\
\hline Natural & $\begin{array}{l}\text { This refers to the atmosphere, land, minerals, forests, water, and wetlands. For the } \\
\text { rural poor, land is an essential asset. }\end{array}$ \\
\hline
\end{tabular}

Sources: Bebbington (1999); Moser and Satterthwaite (2008); Moser (2011)

identification of entry points to inject tailored policy interventions that are necessary to build and fortify the adaptive capacity and resilience of the rural poor (Moser 2011; Moser and Stein 2011). As documented by Moser (2011), individuals are not docile victims but possess resources that they can draw upon in times of crisis. Thus, identifying and strengthening these resources is crucial for the poor to be able to hold their own in times of crisis such as climate variability and change by deploying their available resources to ensure food security.

In the wake of a rapidly changing climate, the injection of tailored policy interventions is desperately needed to scale up food production in SSA and facilitate the actualization of Sustainable Development Goals (SDGs) 1 and 2 (no poverty and zero hunger) by 2030. Against this background, this chapter analyzes the ways in which Indigenous farmers in Igbide, Uzere, and Olomoro communities in the Delta State of Nigeria utilize their bundle of assets to grow their food in the face of a rapidly changing climate. Indigenous, in this context, refers to people that possess a peculiar culture and knowledge distinct to their community that have been examined with real-life scenarios (Ebhuoma 2020).

\section{Research Methodology}

The chapter is based on primary data obtained in Olomoro, Igbide, and Uzere communities situated in Isoko south local government area (ISLGA) of the Delta State in Nigeria (Fig. 1). The mean annual rainfall in the Delta State is between 2500 to $3000 \mathrm{~mm}$ (Adejuwon 2011). Both Igbide and Uzere are low-lying, while Olomoro comprises both high- and low-lying areas. Due to annual heavy rainfall events, the low-lying farmlands are submerged from June to the last week in October. 


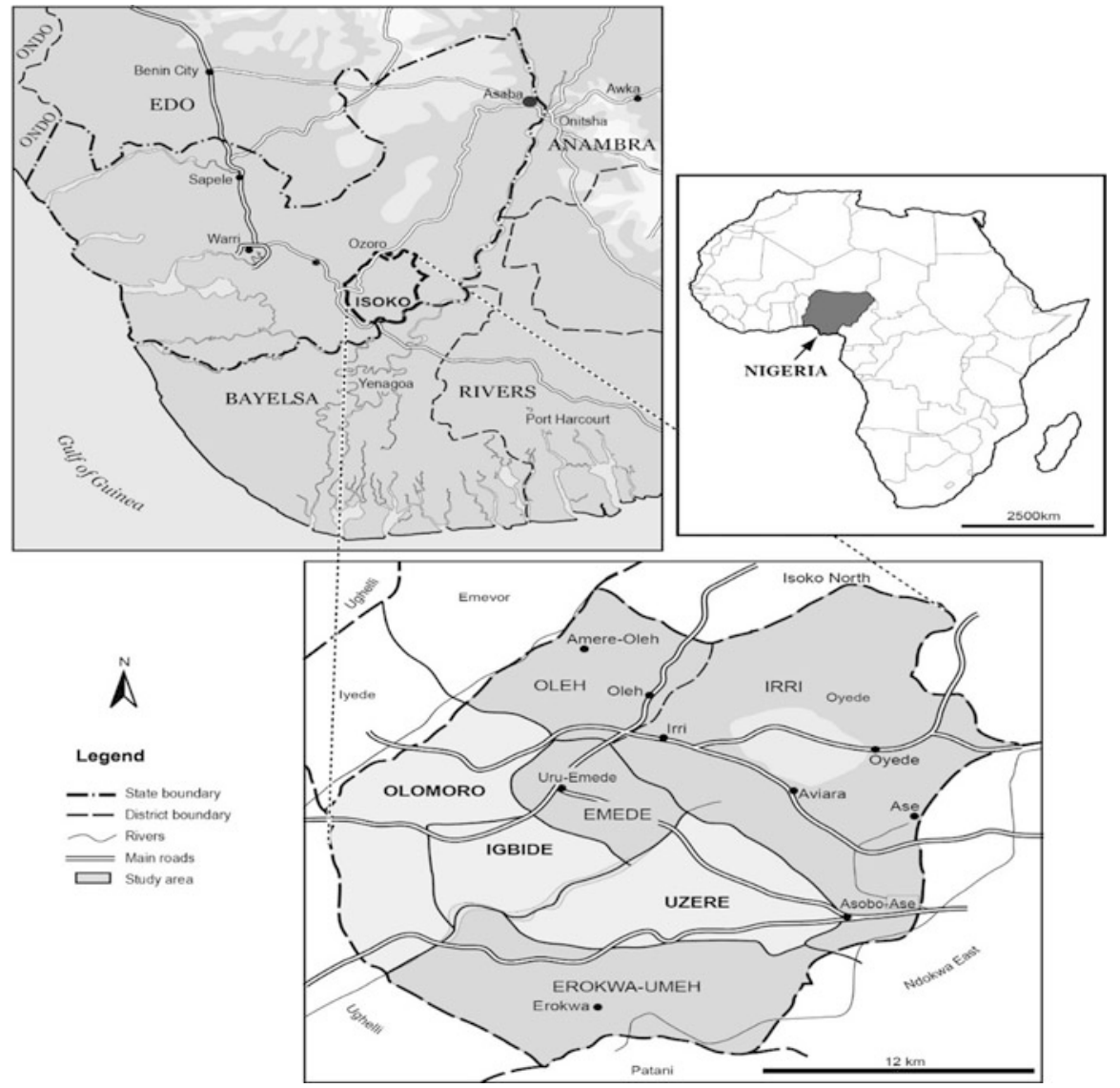

Fig. 1 Map of the study areas. (Source: Cartographic Unit, Wits University, South Africa (2016))

Omohode's (2012) documentation, following the 2012 flood disaster that severely affected most States in Nigeria, influenced the choice of these communities. He highlighted that most low-lying communities in ISLGA were completely submerged, making the area resemble emergency oceans when viewed from a distance. Thus, unpacking the ways in which Indigenous farmers in these communities engage with their bundle of assets will provide valuable insights regarding how vulnerable people grow their food in the face of climatic risks.

The communities are homogeneous in nature. For instance, Isoko, an Indigenous language, is the local dialect spoken. Also, small-scale farming is the major economic driver of these three communities, with the women at the helm of the practice. While some men assist their wives to produce food, they are mostly involved in fishing. In terms of food production, cassava and groundnut are the predominant staples cultivated annually. Cassava makes up approximately $65 \%$ of the total caloric intake in each community. Other cultivated crops include cocoyam, potato, pepper, and plantain. With the exception of cassava which requires a minimum of 6 months to reach maturity, the other crops can be harvested 3 months after planting. 
Focus group discussions (FGDs) and semi-structured interviews were used to obtain primary data. Thirty-five FGDs and four one-to-one, semi-structured interviews (two in Olomoro, one in Igbide and Uzere) were conducted between June and October 2015. Of the 35 focus groups, 24 were made up of female respondents; five comprised male respondents, while six were made of both male and female respondents. Respondents in each FGD varied between 3 and 12 respondents aged between 20 and 85 .

Respondents were identified using purposive sampling based on age, gender, those who have been farming in the study areas for a minimum of 10 years, those whose household assets and livelihoods were severely affected by the 2012 flood disaster, and those that grow their food on low-lying farmlands. Key informants who have lived in each community for over 40 years and an agricultural extension worker facilitated the recruitment of eligible respondents. Primary data retrieved were analyzed using the thematic analysis technique.

\section{Findings}

\section{Livelihood Vulnerability to Climatic Risks}

Respondents pinpointed heavy rainfall events - which resulted in seasonal flooding of low-lying farmlands annually - as the worst weather conditions that undermined effective food production through farmers' inability to maximize their natural capital. In this regard, a respondent from Uzere, in his 80 s, stated:

We are constrained to practice seasonal planting due to flooding which must occur on our farmland annually. Consequently, we must harvest all our cultivated cassava before our farmland gets inundated. This usually worsens food insecurity in times of poor harvest.... This is the advantage farmers in neighboring communities who cultivate on high ground have over us. They do not lack garri (processed cassava) throughout the year.

Seasonal flooding restricts farming for 8 months annually, which has implications for the amount of food farmers are able to produce annually. The second weather conditions that adversely impacted food production are rising temperatures, especially between February and April. On the one hand, respondents aged 40 years and below revealed that the weather has become warmer in the last decade. On the other hand, the elderly respondents ( 50 years and above) argued that the rise in temperature began in the early 1980s. Both groups unanimously acknowledged that in the last 5 years, temperatures between February and April have become abnormally high in the afternoons. This has undermined their ability to work effectively on their farmlands. From the respondents' viewpoint, the adverse effects of the rising temperature are evident in groundnut production as they now harvest empty pods more frequently than in previous times. A respondent from Igbide, in her 50s, asserted:

The sunlight during the months of February and March is really terrible and planting during those months is very difficult. Groundnut is the crop that is seriously affected because it is does not require intense sunlight for optimal productivity. 
Approximately two-thirds of the respondents stated that the change in weather conditions is due to God's making and supernatural forces. When probed about the role of humans in contributing to climate change, most debunked the claim. To concretize this viewpoint, female respondents in a FGD in Igbide unanimously agreed that the change in weather, humans have nothing to do with it; it is solely the making of God. However, the youths attributed the vagaries of weather to the increased rate of deforestation carried out by farmers to obtain firewood. Also, few elderly respondents revealed that the rising temperatures are due to continuous gas flaring activities by Shell's crude oil exploration activities for over 40 years. These three communities have about 62 oil wells that Shell drilled oil from before selling all its oil wells in these communities to the Integrated Data Services Limited (IDSL), a subsidiary of Nigerian national petroleum corporation (NNPC), in 2014. In this light, a male respondent from Uzere, in his 50s, commented:

This community is particularly known for farming. But since the early 1980 s, the quality of both cassava and groundnut produced has reduced significantly. This is due to Shell's oil exploration activities. Most of the youths now engage in off-farm activities because farming can no longer foot their bills.

Most elderly respondents attributed the poor starch content of the garri (processed cassava) they produce to crude oil exploration activities. They lamented that the oil exploration had compromised their soil's nutrients, which in turn has affected the nutritional value of the garri produced, especially when compared to the produce harvested in the 1980s. However, only a few respondents highlighted farmers' inability to engage in bush fallowing, due to increased demand for land stemming from sporadic population growth, as an added factor that has facilitated the reduction in quality of food produced.

\section{Assets and Food Production Nexus}

Due to the annual seasonal floods, farmers employ their human capital to produce cassava on their low-lying farmland through an Indigenous strategy referred to as elelame (follow the water). The other cultivated crops - cocoyam, potato, pepper, and plantain - are produced using the early rains, which usually begins between February and March and last till the end of May. The water strategy commences as soon as the floodwater starts to recede the farmland, usually in November. The farmers' plant their cassava stems on the part of the soil that is visible and moist. They replicate this process until the floodwaters have completely dried up from their farmland. The planting process usually ends between the second and third week in December.

The following year, between June and August, when the rain is heavy and continues to fall consistently, they start harvesting their produce. The decision regarding where to commence harvesting is hinged on their human capital informed by their Indigenous knowledge, as they know the precise portion of their farmland 


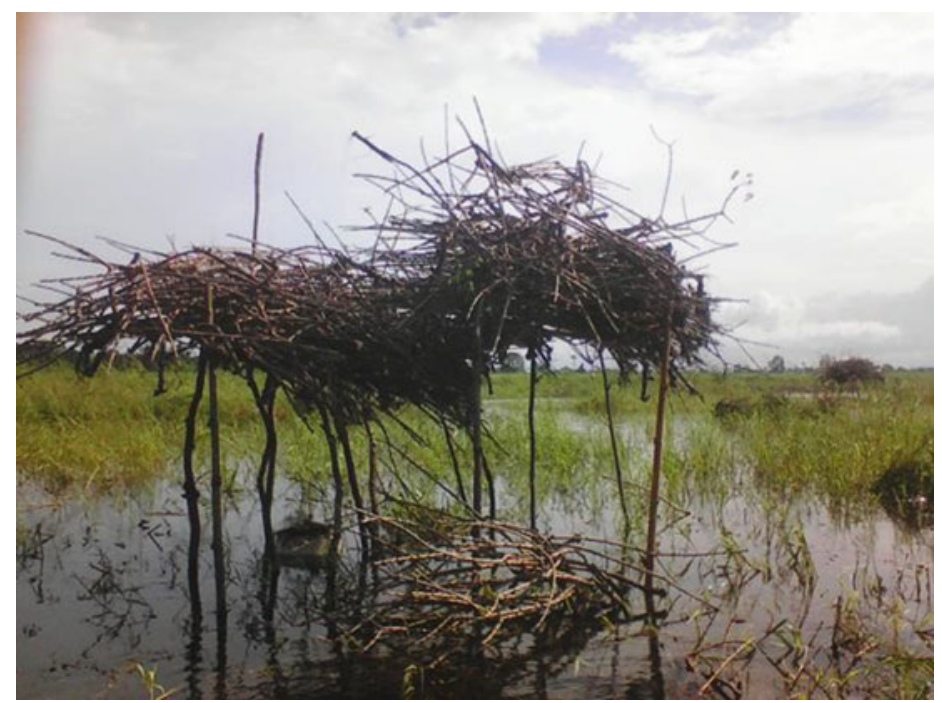

Fig. 2 Indigenous technique used to preserve cassava stem on low-lying farmland. (Photograph: John Ayiko (2015))

that will be submerged at the earliest. Thus, they do not harvest all their farm produce simultaneously. The crop closest to where the inundation will commence are harvested first. The reason for not harvesting all the produce at the same time is because the longer cassava remains in the soil, the bulkier they get. Also, labor shortage is another factor that contributes to adopting this harvesting strategy. Thereafter, usually within a week, they would return - pending on the consistency of rainfall - to their farmland to employ a similar process to harvest the other produce. After harvesting all their produce, they preserve the cassava stems on their inundated farmland by constructing temporary structures to use them for food production in the next planting season (Fig. 2).

To ensure they have garri to eat all year round, they utilize their human capital to process the harvested cassava as well as store it properly. Respondents explained that after the necessary procedures have been implemented, which entail peeling, soaking the cassava in water for several hours, drying the soaked tubers and blending into powdered form, it is fried with little palm oil to an overly dried state. After cooling down, the garri is preserved in airtight sack bags. Thereafter, a wooden structure is constructed and the sack bags placed on top of it. The fundamental reason for suspending the sack bags from the ground is to prevent the garri from going bad through mold formation.

It is noteworthy to mention that some farmers rent farmland, a natural capital, to grow their food. Because most farmers lack financial capital during the planting season, social capital plays a vital role in this regard only for trustworthy individuals. As a respondent from Uzere, in her 40s, highlighted: 
Most farmers lack finances during the planting season. Consequently, only trustworthy individuals are privileged to get farm plots leased to them without having to pay the agreed sum upfront. Often times, they pay the landowners after harvesting and traded some of the produce.

Also, some farmers - due to a shortage of household labor and lack of capacity to hire laborers - drew on their social capital to acquire human capital to facilitate the harvesting of farm produce before the occurrence of the seasonal flooding. Specifically, some farmers depend on neighbors, relatives, and friends to accelerate the harvesting process to avert the possibility of some of the produced cassava from decaying. Furthermore, social capital catalyzed the procurement of financial capital. This is particularly useful as most farmers have been unable to benefit from several loan schemes afforded by the Delta State government against the backdrop of the farm loans being disbursed consistently for over 10 years (United Nations Development Program (UNDP) 2014). Some highlighted that they only hear of farm loans after the application process had closed, a state of affairs which was largely attributed to nepotism.

Although microfinance banks (MFB) in the Delta State have been given directives to provide the rural poor with farm loans, the inability to provide collateral matching the value of the loan sought after or a guarantor with valuable assets has hampered farmers' ability to secure such loans. As respondents in a female-only FGD in Olomoro bemoaned:

Loans exist that could reduce some of the challenges we undergo as farmers, but due to the fact that there is nobody to stand as a guarantor [lack of social capital], they have not been able to harness such opportunities.

Since farmers' annual earnings from food production (between 137 USD to 219 USD) are inadequate to secure their livelihood objectives, they utilize their social capital to temper the financial drought. This is achieved by some community members coming together to form a small group where the prior agreed monetary contributions are made weekly to a trustworthy individual. At the end of each month, the total sum is given to a group member, hinged on prearrangement. This scheme, referred to as $O s u s u$, is useful in ensuring that farmers can purchase items necessary for food production.

\section{Households Still Living Below the Global Poverty Line}

Despite farmers' skillful utilization of their meager bundle of assets at their disposal to ensure continuity in food production, the majority still live under the global poverty line of less than \$US 1.90 a day (Livingston et al. 2011). A fundamental reason for this is due to the low financial gains made from the sale of garri underpinned by its inferior quality when compared with those produced in 
neighboring communities' void of oil exploration activities. Thus, they are "forced" to market their produce at a much-reduced price.

Another factor that impeded farmers from transcending living above the global poverty line is due to the exorbitant interest rate money is borrowed from unregulated bodies such as informal meeting groups and money lenders. Respondents highlighted that not knowing influential people, underpinned by lack of social capital, to act as guarantors to co-sign the credit agreement to access farm loans from MFB is a pull factor toward securing loans from unregulated sources. As some respondents explain, this is prevalent during the planting season as farmers often run out of money having addressed other pressing issues such as paying for both children's tuition fees and levies attached to social responsibility. Thus, farmers are left with no feasible alternative but to obtain loans from "financial predators" as their requirements are less demanding. While the loan obtained enables farmers to produce their food, it proved counterproductive in terms of evading the poverty maze. For example, if a farmer borrows 50 USD for 6 months, the farmer is required to refund the loan with a whopping $40 \%$ interest. This is testament to the fact that the drive to become food secure pushes farmers to do anything within their powers to achieve the objective, regardless of the long-term consequences.

The financial predators are well knowledgeable on the importance of farm loans in ensuring household food security. As a result, they are unwilling to water down their terms and conditions. In this regard, a farmer from Igbide, in his 50s, explained:

Without loans, some farmers cannot grow food. After these farmers secure loan from nongovernment bodies, grow their food and sold some of the produce to refund the loan, most of the time, they are left with little or nothing for the next planting season. The only choice they have is to go back to secure loans from the group that lend them money previously. This is the survival tactic of some farmers in this community.

In fact, the inability to access loan is a catalyst that has made some farmers to engage in off-farm activities. Another factor that compromised effective food production was the lack of physical capital, especially for farmers with access to large hectares of land enough to engage in commercial farming. For example, farmers' inability to access farm machinery dampened their fight to transcend the boundaries of a subsistence farmer. A male respondent in Uzere stated that while the Delta State government usually provides farm equipment for farmers, "it never gets to them." Instead, the equipment is "always hijacked" by influential politicians and close associates of key politicians in the Delta State. In addition, the unavailability of rice milling machines has prevented farmers from producing rice. Few elderly respondents (50 years and above) in Igbide revealed:

In the 1960s, they were actively involved in rice production because of the swampy nature of their farmlands, and rice milling machines provided by the government. But since the 1970s till date, no provision has been made to provide rice milling machines for farmers. As a result, rice cultivation has been abandoned. 
Finally, the farmers lamented bitterly that despite the enormous contributions their communities have made to the nation's foreign revenue for over four decades, their communities have remained shockingly underdeveloped. The lack of good road networks within each community, for example, erodes the financial capital of some farmers, albeit insidiously. To illustrate, during the rainy seasons, it can be challenging for motorists to navigate their way through their community due to countless potholes. This makes accessibility to markets where they have to sell some of their farm produce an exasperating venture.

\section{Discussion}

The adverse effects of climatic risks are palpable in Igbide, Uzere, and Olomoro communities in the Delta State of Nigeria. They have manifested in the form of heavy rainfall events (Ifeanyi-obi et al. 2012), which leads to seasonal flooding of low-lying farmlands, and rising temperatures (Ike and Ezeafulukwe 2015). While these climatic variables have undermined food production, oil exploration activities have aggravated farmers' woes. By significantly degrading soil's nutrients, oil exploration activities have adversely compromised the quality of food produced. This assertion is corroborated by research findings that have also emerged from the Delta State (Ererobe 2009; Elum et al. 2016). Nonetheless, the findings can be disaggregated into two key points.

First, farmers' perception of climate change is underpinned by religious framing. Similar findings have been recorded in Botswana (Spear et al. 2019), Mali (Bell 2014), Nigeria (Jellason et al. 2020), South Africa (Okem and Bracking 2019), and Zimbabwe (Moyo et al. 2012), respectively. Attributing the cause of climate change to oil exploration activities, God and other supernatural forces as well as disentangling their lifestyle activity - deforestation - as a contributing factor seems the logical way for people to continue with the state of affairs without any ill feelings. Accepting how their lifestyle choices may be contributing to climate change, no matter how insignificant it may seem in comparison to gas flaring, for example, will doubtlessly require behavioral changes. In contrast to studies that show that people highly vulnerable to climate change may be more willing to adopt behavioral changes (Akerlof et al. 2013; Azadi et al. 2019), this may not be feasible for farmers in the Delta State due to their quest to obtain their livelihood by any means necessary.

For instance, to rely on kerosene or gas-fueled stoves for cooking may have substantial financial implications in comparison to firewood. In this light, therefore, the need to sensitize farmers on how their actions are contributing to climate change, including the possible future implications for household food security, is essential. This is primarily because rural households in SSA are expected to be adversely affected by the impacts of future climate change (IPCC 2014). Also, it is necessary to involve religious clergies as key stakeholders in the discourse around climate change mitigation as their beliefs and values have the potential to influence the behaviors of their congregation. 
Second, farmers have carved out unique strategies to maximize their meager asset portfolios to produce food despite the increasing threats from climatic risks. The systematic ways in which farmers utilize their human capital to grow food on their low-lying farmlands indicate that farmers are not helpless victims to climatic risks. This is corroborated by findings in Bangladesh (Al Mamun and Al Pavel 2014), Botswana (Motsumi et al. 2012), and Zimbabwe (Mavhura et al. 2013). With the right support and interventions such as providing easy access to loans, machinery, and good road networks, the likelihood that farmers will successfully transcend living above the global poverty line is extremely high. As several studies show (Kochar 1997; Akoijam 2012; Ibrahim and Aliero 2012; Assogba et al. 2017), easy access to government loans remain a major challenge for rural farmers in developing countries. It is documented that the flourishing of exploitative money lenders is due to low priority given to rural credit (Akoijam 2012). Thus, to ensure farmers access farm loans, robust broadcasting of any program through mediums utilized by households to receive vital information are crucial. Otherwise, the persistent dependence on financial predators will continue to flourish, to the detriment of farmers in the Delta State achieving the first SDG.

It should be emphasized that the skillful utilization of social capital to acquire human capital (assistance with cassava harvesting), financial capital (Osusu), and natural capital (not paying the rental before cultivating on farmland) indicates that climate adaptation interventions that may cause fragmentation of households should be avoided. For example, suppose the government wants to provide farmlands on higher grounds to farmers to ensure they can produce food all year round. In that case, farmers in the same community should be given land close to one another. This is crucial for the strengthening of social capital, which is essential to facilitating household food security and ensuring that the country is on the trajectory toward achieving the first (no poverty) and second (zero hunger) SDGs by 2030. As Joshi and Aoki (2014) argue, strong social networks influence household's ability to recover from a disaster.

\section{Final Remarks}

Climatic risks are making life difficult for the farmers cultivating on the low-lying farmlands in Olomoro, Uzere, and Igbide communities. In responding to these threats, Indigenous farmers skillfully employ their limited bundle of assets to continue producing their food. Specifically, this chapter illustrated how human capital plays a pivotal role in ensuring the production of cassava in the low-lying farmlands, which experiences seasonal flooding annually, through an Indigenous strategy referred to as elelame (follow the water). Also, social capital is a crucial asset in farmers' portfolio through its ability to facilitating the procurement of financial capital through a local scheme called Osusu. Further, it enabled the acquisition of natural capital by allowing trustworthy individuals to renting farmlands and only paying the fee after harvesting and selling some of the produce. Since social capital is overwhelmingly fundamental to the achievement of food security, 
any scheme meant to assist farmers to adapt more effectively to climatic risks to produce more food must ensure it creates an avenue for strengthening ties among farmers.

This chapter also finds that despite farmers' ability to attain household food security every year, they still live below the global poverty line. A key factor fuelling this state of affairs is primarily due to the inaccessibility of government loans. Consequently, financially strapped farmers are constrained to secure loans from unregulated sources. While it provides a leeway to continue in food production, it is counterproductive due to the high-interest rates attached to the loans. Perhaps, easing the loan acquisition process from MFB may successfully combat this menace. Otherwise, farmers will be unable to weave their way out of poverty. To conclude, until interventions are geared toward ensuring the protection, strengthening, and making the acquisition of assets that play a fundamental role in food production, chances of successfully achieving the first and second SDGs will be slim.

\section{References}

Adejuwon JO (2011) A spectral analysis of rainfall in Edo and Delta states (formerly mid-western region), Nigeria. Int J Climatol 31:2365-2370

Akerlof K, Maibach EW, Fitzgerald D, Cedeno AY, Neuman A (2013) Do people 'personally experience' global warming, and if so how, and does it matter? Glob Environ Chang 23(1):8191

Akoijam SLS (2012) Rural credit: a source of sustainable livelihood of rural India. Int J Soc Econ 40:83-97

Al Mamun MA, Al Pavel MA (2014) Climate change adaptation strategies through indigenous knowledge system: aspect on agro-crop production in the flood prone areas of Bangladesh. Asian J Agric Rural Dev 4(1):42-58

Assogba PN, Kokoye SEH, Yegbemey RN, Djenontin AJ (2017) Determinants of credit access by smallholder farmers in North-East Benin. J Dev Agric Econ 9(8):210-216

Azadi Y, Yazdanpanah M, Mahmoudi H (2019) Understanding smallholder farmers' adaptation behaviours through climate change beliefs, risk perception, trust, and psychological distance: evidence from wheat growers in Iran. J Environ Manag 250:109456. https://doi.org/10.1016/j. jenvman.2019.109456

Bebbington A (1999) Capitals and capabilities: a framework for analyzing peasant viability, rural livelihoods and poverty. World Dev 27:2021-2044

Bell D (2014) Understanding a "broken world": Islam, ritual, and climate change in Mali, West Africa. J Study Relig Nat Cult 8(3):287-306

Conway D, Schipper ELF (2011) Adaptation to climate change in Africa: challenges and opportunities identified from Ethiopia. Glob Environ Chang 21:227-237

Ebhuoma E (2020) A framework for integrating scientific forecasts with indigenous systems of weather forecasting in southern Nigeria. Dev Pract 30:472-484

Ebhuoma O, Gebreslasie M (2016) Remote sensing-driven climatic/environmental variables for modelling malaria transmission in sub-Saharan Africa. Int J Environ Res Public Health 13 (6):584. https://doi.org/10.3390/ijerph13060584

Elum ZA, Mopipi K, Henri-Ukoha A (2016) Oil exploitation and its socioeconomic effects on the Niger Delta region of Nigeria. Environ Sci Pollut Res 23:12880-12889

Ererobe M (2009) FG, multinationals and Isoko nation. https://www.vanguardngr.com/2009/08/fgmultinationals-and-isoko-nation/. Accessed 3 Apr 2020 
Fitchett JM, Robinson D, Hoogendoorn G (2017) Climate suitability for tourism in South Africa. J Sustain Tour 25(6):851-867

Ibrahim SS, Aliero HM (2012) An analysis of farmers' access to formal credit in the rural areas of Nigeria. Afr J Agric Res 7:6249-6253

Ifeanyi-obi C, Etuk U, Jike-wai O (2012) Climate change, effects and adaptation strategies: implication for agricultural extension system in Nigeria. Greener J Agric Sci 2:53-60

Ike PC, Ezeafulukwe LC (2015) Analysis of coping strategies adopted against climate change by small scale farmers in Delta state, Nigeria. J Nat Sci Res 5:15-24

Intergovernmental Panel on Climate Change (IPCC) (2014) Africa. Intergovernmental Panel on Climate Change. https://www.ipcc.ch/pdf/assessment-report/ar5/wg2/WGIIAR5-Chap22 FINAL.pdf. Accessed 25 Sept 2020

Jaroszweski D, Chapman L, Petts J (2010) Assessing the potential impact of climate change on transportation: the need for an interdisciplinary approach. J Transp Geogr 18:331-335

Jellason NP, Conway JS, Baines RN (2020) Exploring smallholders' cultural beliefs and their implication for adaptation to climate change in North-Western Nigeria. Soc Sci J. https://doi.org/ $10.1080 / 03623319.2020 .1774720$

Joshi A, Aoki M (2014) The role of social capital and public policy in disaster recovery: a case study of Tamil Nadu state, India. Int J Disaster Risk Reduct 7:100-108

Kochar A (1997) An empirical investigation of rationing constraints in rural credit markets in India. J Dev Econ 53:339-371

Livingston G, Schonberger S, Delaney S (2011) Sub-Saharan Africa: the state of smallholders in agriculture. http://www.ifad.org/documents/10180/78d97354-8d30-466e-b75c-9406bf47779c. Accessed 12 June 2015

Mavhura E, Manyena SB, Collins AE, Manatsa D (2013) Indigenous knowledge, coping strategies and resilience to floods in Muzarabani, Zimbabwe. Int J Disaster Risk Reduc 5:38-48

Moser C (2011) A conceptual and operational framework for pro-poor asset adaptation to urban climate change. http://siteresources.worldbank.org/INTURBANDEVELOPMENT/Resources/ 336387-1256566800920/6505269-1268260567624/Moser.pdf. Accessed 25 Sept 2020

Moser C, Satterthwaite D (2008) Towards pro-poor adaptation to climate change in the urban centers of low- and middle-income countries. http://pubs.iied.org/pdfs/10564IIED.pdf. Accessed 25 Sept 2020

Moser C, Stein A (2011) Implementing urban participatory climate change adaptation appraisals: a methodological guideline. Environ Urban 23:463-485

Motsumi S, Magole L, Kgathi D (2012) Indigenous knowledge and land use policy: implications for livelihoods of flood recession farming communities in the Okavango Delta, Botswana. Phys Chem Earth A/B/C 50-52:185-195

Moyo M, Mvumi BM, Kunzekweguta M, Mazvimavi K, Craufurd P, Dorward P (2012) Farmer perception of climate change and variability in the semi-arid Zimbabwe in relation to climatology evidence. Afr Crop Sci J 20:371-333

National Bureau of Statistics (NBS) (2014) Delta state information. http://www.nigerianstat.gov.ng/ information/details/Delta. Accessed 22 Dec 2015

Nelson G, Rosegrant MW, Koo J, Robertson R, Sulser T, Zhu T (2014) Climate change impact on agriculture and costs of adaptation. http://www.ifpri.org/sites/default/files/publications/pr21. pdf. Accessed 11 July 2015

Okem AE, Bracking S (2019) The poverty reduction co-benefits of climate change-related projects in eThekwini Municipality, South Africa. In: Cobbinah P, Addaney M (eds) The geography of climate change adaptation in urban Africa. Palgrave Macmillan, Cham. https://doi.org/10.1007/ 978-3-030-04873-0_10

Omohode R (2012) How massive flood swept away 50 Isoko communities, rendered thousands homeless. http://www.urhobotimes.com/individual_news.php?itemid=820. Accessed 6 Apr 2015 
Perez C, Jones EM, Kristjanson P, Cramer L, Thornton PK, Förch W, Barahona C (2015) How resilient are farming households and communities to a changing climate in Africa? A genderbased perspective. Glob Environ Chang 34:95-107

Spear D, Selato JC, Mosime B, Nyamwanza AM (2019) Harnessing diverse knowledge and belief systems to adapt to climate change in semi-arid rural Africa. Clim Serv 14:31-36

United Nations Development Programme (UNDP) (2014) Delta State development performance: agricultural sector report, 1991-2014. http://www.undp.org/content/dam/nigeria/docs/ IclusiveGrwth/UNDP_NG_DeltaState_Agric_2015.pdf. Accessed 15 Nov 2015

Open Access This chapter is licensed under the terms of the Creative Commons Attribution 4.0 International License (http://creativecommons.org/licenses/by/4.0/), which permits use, sharing, adaptation, distribution and reproduction in any medium or format, as long as you give appropriate credit to the original author(s) and the source, provide a link to the Creative Commons license and indicate if changes were made.

The images or other third party material in this chapter are included in the chapter's Creative Commons license, unless indicated otherwise in a credit line to the material. If material is not included in the chapter's Creative Commons license and your intended use is not permitted by statutory regulation or exceeds the permitted use, you will need to obtain permission directly from the copyright holder.

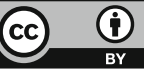

